\title{
DO FUND SIZE, STYLE AND RATING EXPLAIN PERFORMANCE?
}

\author{
Jacob M Ongaki \\ Colorado Mesa University, USA
}

\begin{abstract}
The purpose of this quantitative investigation was to examine whether performance (1-Year, 3-Year, and 5-Year annual returns) differences exist among fund categories by size and style (large-cap growth, large-cap blend, mid-cap growth, and small-cap growth) and fund ratings (5-Star and 4-Star) controlling covariate variables (standard deviation, turnover rate, and top-10 holding) of the United States equity MFs. Morningstar Inc. provided an insightful measure of fund performance annual returns and fund efficacy ratings. The study utilized the Analysis of Covariance and Multivariate Analysis of Covariance methods. The investigation revealed that the large-cap growth fund category produced superior annual returns than other fund families. The five-star-rated funds performed better than the four-star-rated funds. Turnover and top-10 percentage asset holdings had a statistically significant effect on fund annual performance. Investors and asset managers should consider the fund style, size, fund ratings for making short-term, medium, and long-term financial investment decisions.
\end{abstract}

Keywords: mutual fund, fund style, fund size, fund ratings, market return

ARTICLE INFO

Article History:

Received: 30 December 2020

Accepted: 21 April 2021

Published: 31 August 2021

* Corresponding Author: Jacob M Ongaki. E-mail: jongaki@coloradomesa.edu 


\section{INTRODUCTION}

Mutual Fund (MF) has become attractive and grown in popularity among investors primarily because of diversification and competitiveness returns (Walia \& Kumar, 2013). The MFs were favorable in the late 1990s but experienced a decline in mid-2000 through mid-2003 (ICI - Fact Book 2010). The Investment Company Institute (ICI-2019) approximated 99.5 million Americans and 56.0 million households invested in MF in 2018 to achieve short and long-term financial goals (Galagedera et al., 2018). Although MFs provide many benefits, investors need to be cautious about increased expense ratios associated with a fund turnover ratio. Despite the body of research on MF (performance, risk, expense ratios, tax), not a single study (according to the best of our knowledge) considered annual fund performance relative to fund size, styles, fund ratings, and covariates. Fund size may include large-cap, mid-cap, and small-cap funds (Shi \& Seiler, 2002). Fund style may include growth, blend, and value funds (Shi $\&$ Seiler, 2002). This study aimed to determine whether fund size and style produce different and equitable performance results (Arshanapalli et al., 2007). We refer to fund size and style as the fund category in this study. Fischer and Overkott (2015) investigated the performance of 4,147 MF categories and found that reveal funds are indifferent and produced poor Alpha. These funds exhibited time-varying risk premium exposures. The value funds (loading) and growth funds decreased momentum loading during the periods of expected market risk premium (Fischer \& Overkott, 2015). Do the Morningstar fund ratings (1-5-star ratings) have significant efficiency (Watson et al., 2011)? This study will explore the fund categories and the 1 , 3 , and 5 annual return ratings return while controlling for standard deviation or total risk (STD), fund turnover ratio (TO), and the percentage of the top-ten holdings in assets (Top10-H). The TOP10-H is defined as a higher percentage in the top-10 total asset fundholding or the more concentrated the fund in a few companies (Bello \& DeRidder, 2010).

Many financial asset management firms utilize the Morningstar rating system and the fund categories for investment purposes (Watson et al., 2011). The performance of MF may be driven by sector and industry investment concentration (Goldman et al., 2016). The sector/industry concentrations may include energy, financial services, health care, precious metals, real estate, technology, and utilities (Fitzpatrick et al., 2012). The performance 
expectation for investors is high for fund styles equity MF fund categories such as the Morningstar rating (Shi \& Seiler, 2002). We extend this investigation to fund categories and fund ratings.

There is a general belief that the growth funds perform better than blend and that blend funds perform better than value funds about 1-Year (1-YR), (3-YR), and 5-Years (5-YR) annual returns (total return). Hsu et al. (2016) argued that the timing of an investment (in and out of MF) plays a big role to realize substantial returns compared to a buy-and-hold strategy. This could be true for investors' ability to invest in value MF by entering the fund before expected higher returns and out of value before an expected poor performance. Outside the stated boundaries the expected benefits from value funds diminish by 2 percent. This is true for an average fund investor (Hsu et al., 2016). The investigation further suggested that the return is lower in growth funds than value funds and even a bigger gap in larger-cap than small-cap funds (Hsu et al., 2016). Arshanapalli et al. (2007) investigated the style-timing fund families based on a multinomial logit model and concluded a better portfolio performance. Investors should incorporate the timing of fund size and style to realize excess returns factoring fundamental and technical analysis (Arshanapalli et al., 2007). The question remains whether the performances hold when controlling for the fund standard deviation, the top-10 percentage holding, and the turnover percentage rate (covariates).

The Morningstar fund valuation and efficacy (Blake \& Morey, 2000) may be based on the fund's historical rating performance for 5-Star than 4-Star funds (Watson et al., 2011; Blake \& Molly, 2002). There has been an ongoing debate among researchers and financial analysts whether growth funds perform better compared to blend and value funds in terms of 1-YR, 3-YR, and 5-YR annual returns. However, funds are generally affected by many factors: STD (total risk), the TO, and the TOP10-H. We examined whether a difference exists considering covariates. In the periods after the 2008 recession, many funds produced 19.67 percent for a fiveyear annualized return compared to the S\&P 500 index of 17.94 percent return (Fan, 2018). The small-cap funds performed well in the five-year annualized return compared to large and mid-cap funds. Bekaert and $\mathrm{Wu}(2000)$ suggested that the below-average funds were associated with increased standard deviation based on asymmetric volatility. The study 
investigated 367 US equity funds within five years. Popescu and Xu (2017) concluded that those funds (poor performing funds) assumed increased risk in expansionary and boom periods and vice versa for contracting and recessionary periods. The investigation findings were consistent with an earlier study (Kacperczyk et al., 2008). Blake and Morey (2000) found that higher-rated funds ( 5 and 4 stars) could not help predict future performance and investors should be wary of using the rating metrics, however, the large-value funds' five-year Alpha was significant considering risk-adjusted returns (Fan, 2018). Fund performance and risk depend on the business's economic cycle. Investors adjust their risk depending on whether a boom or recessionary period that ultimately affects performance (Popescu $\& \mathrm{Xu}$, 2017). Shi and Seiler (2002) found that neither the growth nor value funds produced superior returns compared to a benchmark concerning fund size. However, the growth and value funds returned better results relative to their small fund classification (Chen et al., 2004). The result did not hold when controlling for fund size. The result was mixed for medium size counterpart funds (Shi \& Seiler, 2002). The studies' inconsistencies have prompted this investigation to fill the gap. We examined whether the Morningstar fund ratings and fund classifications could shed light to predict future portfolio investment returns considering STD, the TO, and TOP10-H.

\section{LITERATURE REVIEW}

The performance of MF investment (stocks, bonds, MF, and others) depends on favorable and unfavorable market conditions. The fund categories (Table 1) of domestic US equity MF investments have grown largely because of their popularity in diversification to mitigate unsystematic risk and maximize returns. The Morningstar may help investors to determine fund performance based on fund size and style and the fund star ratings. Morningstar provides the fund rating system and fund investment categories to help investors filter through thousands of MF. The fund ratings and fund categories may provide valuable information to predict the fund's future performances (Shi $\&$ Seiler, 2002). Besides the aforementioned factors, investors may consider market risk (beta) or systematic risk, total risk (standard deviation), fund turnover (sales), the top-level holdings (assets), price earning, price-book ratio, and taxes to make future investment financial decisions. The ultimate investment strategy is to maximize short and long-term expected returns 
(1-YR, 3-YR, and 5-YR annual returns) at any given period. The question is whether the Morningstar fund rating system predicts future performance. For example, do the 5-Star rated funds perform better than the 4-Star funds (Shi \& Seiler, 2002)? This study examined the performances of the 5-Star and 4-Star ratings US equity MF controlling the fund's standard deviation, the fund's turnover rate, the top- 10 holding in assets. We further examined the performances of the categories of the US equity MF controlling the fund's standard deviation, the fund turnover ratio, the top-10 holding in assets. Prior studies have produced mixed results in terms of fund category and fund ratings about fund performances (1-YR, 3-YR, and 5-YR annual returns).

Shi and Seiler (2002) investigated 180 funds of different investment categories with mixed results. With disregard to size, the result for value and growth funds indicated a higher risk and return (Shi \& Seiler, 2002). Mid-cap growth funds and small-cap funds presented a higher fund risk (Shi \& Seiler, 2002). The large and medium funds (value and growth) produced superior returns compared to the small-cap index or Russell 2000 benchmark (Shi $\&$ Seiler, 2002). Badrinath and Gubellini (2012) suggested that small and medium active growth fund tends to achieve superior returns by reducing the fund risk exposure compared to passive portfolio investment strategy (index) during bad economic market conditions. The value funds stock portfolios are susceptible to risk and may not realize such superior returns (Badrinath \& Gubellini, 2012). Another study that explored equity mid-cap MF in the periods 2010 and 2013 (Panda \& Moharana, 2014) indicated that the lower risk investment in mid-cap funds ( $80 \%$ of the sample size) outperformed the benchmark. Milan and Eid (2014) found that high turnover rates of funds negatively affected MF performance. It was noted that there were no superior returns relative to passive investment considering the fund's turnover transaction costs and fees. Cremers and Petajisto (2009) who examined trading transaction costs (before and after) suggested that the lower turnover rate funds resulted in below-average performance compared to the benchmark. Wermers (2000) indicated that high turnover rate funds produced the highest returns despite high transaction costs and charges. However, Chen et al. (2000) suggested that those funds traded for a short period. Gupta-Mukherjee (2013) indicated that funds with a higher historical turnover rate generated superior returns. Kaushik and Barnhart (2009) found a positive correlation between fund performance, the TOP10-H, and fund turnover ratio. The study sample of 72 months 
included the period between 2001 and 2006 of 4,640 (monthly returns) funds (Kaushik \& Barnhart, 2009). The TOP10-H or top quartile funds than the bottom quartile funds experienced excess monthly returns compared to the S\&P 500 index by 410 basis points or 49.2 percent in annual returns. The bottom tier funds underperformed (Kaushik \& Barnhart, 2009). This result suggested that the higher turnover ratio for a percentage of investment within the TOP10-H or the higher weighted holdings in assets produced superior (abnormal) returns than their predecessors (Kaushik \& Barnhart, 2009). The poor performing portfolio was positively related to load and size funds. Rakesh (2012) suggested that a higher percentage of funds that produced higher returns (funds that beat the market) were correlated with higher risks. This result was supported in another investigation by Babalos et al. (2015). This notion confines with the principle of finance (risk and return tradeoff). An earlier study by Arugaslan et al. (2007) indicated that the funds that produced the highest return lost their performance superiority when factoring in the fund's inherent risk. The case holds to more attractive and low-risk funds (Arugaslan et al., 2007). Vijayakumar et al. (2012) analyzed fund characteristics (market return, standard deviation, fund size, turnover ratio, income ratio, and expenses ratio) and found possible return associations. The risk (STD), fund size, and expense ratio were associated with a higher return than turnover rates that showed an inverse relationship. Walia and Kumar (2013) suggested that fund managers could not maximize Return on Equity (ROI) by investing heavily in risky assets without considering product quality, business cycle, and the risk-return tradeoff of the investment portfolio. Karoui and Meier (2015) concurred that low-performing funds than the average funds experienced higher standard deviation and return. The volatilities are explained by fund managers' shift in buy-and-hold strategies. The study examined 5,565 actively managed funds of U.S. equity MF for the holding period between 1991 and 2010. The large-cap MF mimics the index and investors consider a fund's category as an investment strategy. Yalavatti and Bheemanagouda (2017) found that large-cap equity MF produced better market returns compared to the benchmark (NSE Nifty 50) on all metrics categories in India. Manju (2011) concluded that the performance of the MF versus the market is a win-win situation in which some funds performed better than the market and vice versa. An earlier study concluded that MF categories could provide pertinent information to individual investors and fund managers to formulate a future winning portfolio (Swinkels \& Tjong-A-Tjoe, 2007). 
Investors' sentiments are both irrational and rational depending on market conditions that attribute to the risk (BU, 2019). The large-cap stock funds tend to follow the market momentum investment strategy as opposed to the diversification features of large-cap blend funds (Ang et al., 2017). Herrmann et al.'s (2016) concurred that style-shifting of MF investment strategy not only predicted future performance but also earned $2.4 \%$ in higher returns than past returns. The study included 2,631 daily returns of US active equity MF. Goldman et al. (2016) indicated that industrysector concentration of one or two top 10-industry sectors produced better performance results considering market conditions such as industry concentration index, size, and the fund's investment objectives. The result did not hold in a study by Ang et al. (2017). The investigation suggested that large shareholding funds produced better returns even when controlling the fund size and fees. Patel (2018) recommended a portfolio simplification strategy by reducing expenses to optimize fund performance.

Despite increased research in MF returns, a few studies have investigated the fund categories and the fund ratings as significant factors that affect portfolio returns. The latest study we could find goes back to 2002 (Shi \& Seiler, 2002). The study examined US equity MF in six categories over six years. The investigation examined fund sizes and style annual returns considering per unit of risk (Shi \& Seiler, 2002). Babalos et al. (2015) investigated fund size and fund risk and concluded that the fund with higher risk produced superior performance. The result was mixed concerning large-cap funds. There was some evidence in support of large-cap funds except for funds within certain sectors/industries (technology). This study explored fund categories (LG, LB, MG, SG) and the Morningstar fund ratings (5 and 4-star rated funds) to make informed investment choices and to estimate future expected returns (1-YR, 3-YR, and 5-YR annual returns). This research would shed light to determine whether fund categories and Morningstar ratings produce different annualized returns considering study controlling variables.

\section{Research Objective}

The investigation examined whether the Morningstar fund categories by size (large, mid, and small-cap) and style (growth, blend, and value funds) of US equity MF have any predictive power to evaluate future performance 
(1-YR, 3-YR, 5-YR annualized returns) controlling covariates (STD, the TO, and TOP10-H). The large-cap funds include large-cap growth, largecap blend, and large-cap value funds. We further explored whether the Morningstar fund ratings (5-Star and 4-Star ratings) systems were different in assessing fund performances (1-YR, 3-YR, and 5-YR annualized returns) controlling covariates (STD, the TO, and TOP10-H). The following were the research hypotheses.

Hypotheses 1: The US equity MF large-cap growth, large-cap blend, mid-cap growth, and small-cap growth perform differently in 1, 3, and 5 -year annual returns controlling standard deviation, turnover rate, and top-10 asset holding.

Hypotheses 2: The US equity MF large-cap growth, large-cap blend, mid-cap growth, and small-cap growth 5-star rated fund are related to higher 1, 3, 5-year annual returns than the 4-star rated funds controlling standard deviation, turnover rate, and top-10 asset holding.

\section{METHODOLOGY}

\section{Data}

This study examined whether performance (1-YR, 3-YR, and 5-YR) differences exist among the US equity MFs investment categories (largecap growth, large-cap blend, mid-cap growth, and small-cap growth) while controlling covariate variables (STD, the TO, TOP10-H). The research data was obtained from the Morningstar database system. The none-US equity funds, bonds funds, international funds, and other funds were excluded from this study. The data period assumed 5 years ending in 2019 and as calculated in the Morningstar Inc. database system. Many researchers have utilized the database to extract reliable data and valuable information (Galagedera et al., 2018). The database includes funds' annual returns, total net assets, the fund investment objectives, expense ratios, turnover ratios, tax ratios, risk, and other relevant characteristics for MF (Park, 2016). The specific data included annualized returns for 1-Year (1-YR), 3-Year (3-YR), and 5-Year (5-YR) as Dependent Variables (DV) and Standard Deviation (STD), the top-10 percentage holding in assets (Top10-H), and the fund turnover rate 
percentage (TO) as covariates variables in this research. The fund groups (LG, LB, MG, and SG) and 5 and 4-star ratings were categorical Independent Variables (IV). The Morningstar return assumes the reinvestment calculation of income and capital gains distributions (Shi \& Seiler, 2002). The funds may include active and passively managed domestic equity MF. The funds selected were from nine investment fund categories and fund ratings.

The mutual fund industry classifies by size and style as shown in Tables 1 and 2. The Morningstar data was exported to excel and imported to SPSS software version 24. The final sample size of the US equity MF included 894 funds of actively and passively managed funds (Table 2). The large-cap growth fund category with the largest mean of 30.61, 22.34, and 15.61 for 1-YR, 3-YR, and 5-YR, respectively (Table 2). However, the standard deviation varied across fund categories. The highest standard deviation for 1-YR mid-cap growth-5.01 and an average mean of 4.82, the highest standard for 3-YR mid-cap growth-3.17, and an average mean of 3.61, and the highest standard for 5-YR small-cap growth-1.88 and an average mean of 1.95 (Table 2). The detailed descriptive statistics for the fund categories and fund star ratings ( 5 and 4 star and means, variances, maximum, minimum, skewness, and kurtosis) and annual returns (1-YR, 3-YR, and 5-YR) of the US equity MF are shown in the Appendix 1 and 2. It appears that the large-cap growth funds suggest higher returns and moderate standard deviation. The skewness and kurtosis were within the normal data distribution range with a few exceptions as shown in Appendix 1 and 2.

Table 1: Mutual Fund Categories

\begin{tabular}{llll}
\hline Size & Market Cap (Assets \$ Billions) & \multicolumn{1}{c}{ Style } & Growth Rate \\
\hline Small-Cap & $2 \leq$ & Growth & Higher \\
& & Blend & Mix Rates \\
& & Value & Undervalued \\
\hline Mid-Cap & $>2 \& 10 \leq$ & Growth & Higher \\
& & Blend & Mix Rates \\
& & Value & Undervalued \\
\hline Large-Cap & $\geq 10$ & Growth & Higher \\
& & Blend & Mix Rates \\
& & Value & Undervalued \\
\hline
\end{tabular}

Source: Own 
Table 2: Descriptive Statistics

\begin{tabular}{lllcc}
\hline & \multicolumn{1}{c}{ FD Cat Coded } & Mean & Std. Deviation & N \\
\hline 1-YR & Large-cap Growth & 30.61 & 3.84 & 350 \\
& Large-cap Blend & 25.37 & 1.72 & 241 \\
& Mid-cap Growth & 27.17 & 5.01 & 164 \\
& Small-cap Growth & 22.39 & 4.46 & 139 \\
\cline { 2 - 5 } & Total & 27.29 & 4.82 & 894 \\
\hline 3-YR & Large-cap Growth & 22.34 & 2.58 & 350 \\
& Large-cap Blend & 15.69 & 1.13 & 241 \\
& Mid-cap Growth & 20.10 & 3.17 & 164 \\
& Small-cap Growth & 19.76 & 2.77 & 139 \\
\cline { 2 - 5 } & Total & 19.73 & 3.61 & 894 \\
\hline 5-YR & Large-cap Growth & 15.61 & 1.41 & 350 \\
& Large-cap Blend & 12.09 & 0.61 & 241 \\
& Mid-cap Growth & 13.79 & 1.45 & 164 \\
& Small-cap Growth & 13.81 & 1.88 & 139 \\
\cline { 2 - 5 } & Total & 14.05 & 1.95 & 894 \\
\hline
\end{tabular}

Source: Own

\section{Methodology}

This quantitative study examined whether performance (1-YR, 3-YR, and 5-YR, differences exist among the US equity MF investment categories (large-cap growth, large-cap blend, mid-cap growth, and small-cap growth) while controlling for covariate variables (STD, the TO, TOP10-H). The ANCOVA and MANCOVA research method design enabled the investigation. The ANCOVA and MANCOVA were sufficient to examine two-way tests. The three DV, the fund categories of 4-levels (IV), and three covariate variables. The design allowed us to investigate the fund association among groups and sub-groups (size and style and fund star ratings) considering confounding variables (STD, the TO, and TOP10-H). The fund ratings were based on the fund efficacy (fund performance, transaction cost, risk, and total returns) provided within the Morningstar calculations (Watson et al. 2011). The higher the fund-star rating the higher its efficacy that translates to higher performance. The adjusted risk is associated with sales transaction costs in comparison to similar funds (size and style). The top 10 percent of funds receive five-star ratings, and 
the bottom 10 percent receive one-star ratings (Fan, 2018). The annualized returns calculation for 1-YR, 3-YR, and 5-YR includes the geometric mean of a fund's annual net returns (Fan, 2018). The Morningstar annualized total rate of return (includes distribution reinvestment of income and capital gains) is computed by dividing the change in NAV (Net Asset Value) by the initial NAV (Shi \& Seiler, 2002). The fund's performance compared to other similar fund categories (Shi \& Seiler, 2002). The large-cap value, mid-cap blend, and value, and small-cap blend and value were removed from the final sample size because of the low sample size and to avoid skewness and type 1 and 2 errors. The final sample included 894 funds of LG, LB, MG, and SG and five and four-star fund ratings (Table 2). The large-cap growth and blend funds were represented in a higher percentage compared to all other categories (mid-cap and small-cap growth) funds. The annual performance returns and other measurement information reflected the S\&P 500 index or market benchmark. The market benchmark or index performance was not analyzed for this study. The term covariates, controlling, confounding, or intervening variables were used interchangeably used in this investigation.

This study would be beneficial for fund managers and individual investors to examine fund categories when making financial investment decisions. The identification of suitable fund categories and ratings may provide valuable short and long-term investment goals (time horizon). We further examined whether the Morningstar fund ratings (five and four and star) are beneficial to investors for making financial investment decisions factoring in intervening variables. Because of the nature and limited scope of this investigation, price earning, and book price ratios were not evaluated in this study, an opening study in future research. The research data and methodology assumed the following factors.

1. The research data (fund ratings, the fund categories, and the associated performances of US MF generated from the Morningstar Inc. system.

2. Expense and tax were excluded from the study (complexity of obtaining consistent and associated relevant data).

3. The funds examined in this study included annualized returns for 1-YR, 3-YR, and 5-YR presumed for the five years ending 2019. 
4. The Morningstar fund size, styles, fund ratings, and time horizon were assumed to be consistent with the historical returns. We further assumed the same information provided to prospective investors considering MF investment in various business cycles and markets (market gains and losses alike).

5. The domestic US equity MF included investment size and style (such as large-cap growth, large-cap blend, mid-cap growth, and small-cap growth funds).

6. The parametric Analysis of Covariance (ANCOVA) and Multivariate Analysis of Covariance (MANCOVA) methods were utilized.

7. The covariates variables were utilized in the research methodology to reduce error variance and thus to increase outcome precision power without obscuring the phenomenon and the study outcome.

\section{Assumptions}

The assumptions for the ANCOVA/MANCOVA method were satisfied for data residuals normally distributed, no extreme outliers (extreme outliers removed), independent sample, homoscedasticity, and no missing cases of the US equity MF. The Shapiro-Wilk indicated a statistically significant result that data was not confining to the normality test $(\mathrm{P}<.05)$. However, several visual inspections such as Q-Q plots, Kurtosis, and skewness (within \pm 1 range with a few exceptions), and histograms showed a normal dataset to satisfy ANCOVA/MANCOVA assumption requirements. The scatterplot showed a linear relationship between covariates (STD, the TO, and Top 10-H) and dependent variables (five and four fund star rating and fund categories-LG, LB, MG, and SG). The outliers were transformed by winsorizing within \pm 3.29 in the data range based on standardized residuals in SPSS. The skewness and kurtosis are a robust measure for normally distributed data (Field, 2013) and data within \pm .5 range is approximately symmetric (D'Agostino \& Stephens, 1986). The covariates (STD, the TO, and TOP10-H) were not highly correlated (the highest was less than 0.4 based on the Pearson correlation matrix). The Pearson correlation matrix between DVs was less than 0.9, however, the 3-YR vs. 5-YR correlation was .89. Tabachnick and Fidell (2012) suggest that no correlation should 
be above $r=.90$ for ANCOVA/MANCOVA assumptions. The Leven's and Box's test results were significant $(\mathrm{P}<.05)$ homogeneity of equality variance violated. The interaction between covariates and independent variables showed mixed results. In any case, the assumptions were fairly satisfied to move forward with the study. The following sections include a literature review, methodology, results, and conclusion.

\section{RESULTS}

The study was in two parts. First, to determine performance (1-YR, 3-YR, and 5-YR annual returns) statistical significance difference among fund categories (LG, LB, MG, and SG) of US equity MF controlling covariate variables (STD, the TO, TOP10-H). Second, to determine performance (1-YR, 3-YR, and 5-YR annual returns) statistical significance difference between five and four-star fund rating of US equity MF controlling covariate variables (STD, the TO, TOP10-H). The Wilks Lambda MANCOVA multivariate test result was statistically significant $(\mathrm{P}<.05)$. The annual returns (1-YR, 3-YR, and 5-YR) for five and four-star fund ratings and the fund categories (LG, LB, MG, and SG) were statistically significant controlling covariate variables (STD, the TO, TOP10-H). The P-value was significant $(\mathrm{P}<.05)$ with a $3.4 \%$ effect size (partial Eta Squared) as shown in Table 3. The Wilks' Lambda result in isolation indicated that the fund star rating had a bigger effect of 39 percent compared to fund categories of 26 percent (Table 3 ). The covariate asset turnover was not a statistically significant effect $\mathrm{P}>.27$ at the multivariate test level (Table 3 ). The fund star rating (five and four-star) result was statistically significant $(\mathrm{p}<.05)$ for fund categories related to annualized returns (1-YR, 3-YR, and 5-YR) controlling STD, the TO, TOP10-H with .39 effect size (Partial Eta Squared) as shown in Table 3. The fund categories (LG, LB, MG, and SG) result was statistically significant $(\mathrm{p}<.05)$ for fund categories related to annualized returns $(1-\mathrm{YR}$, $3-\mathrm{YR}$, and 5-YR) controlling covariates variables (STD, the TO, TOP10-H) Wilks' Lambda .26 effect size (Partial Eta Squared) as shown in Table 3. The tests of between-subjects effect were statistically significant $(\mathrm{P}<.05)$ for fund category, fund star rating relative to 1, 3, and 5-year annualized return (Appendix 4). The univariate tests were statistically significant ( $\mathrm{P}$ $<.05$ ) for fund categories without the Morningstar star ratings (Table 4). The annualized return effect size controlling covariates was approximately 
$0.21,0.40$, and 0.37 for $1-Y R, 3-Y R$, and 5-YR, respectively (Table 4). The covariate effect differences before and after covariates were $0.18,0.14$, and 0.16 for 1-YR, 3-YR, and 5-YR, respectively.

Table 3: Multivariate Tests (Fund Categories \& Ratings)

\begin{tabular}{ccccccc}
\hline Effect & Test Type & Value & F & Error df & Sig. & $\begin{array}{c}\text { Partial Eta } \\
\text { Squared }\end{array}$ \\
\hline Intercept & $\begin{array}{c}\text { Wilks' } \\
\text { Lambda } \\
\text { Wilks' }\end{array}$ & 0.354 & 534.73 & 881 & .00 & .65 \\
$\begin{array}{c}\text { Deviation } \\
\text { Turnover }\end{array}$ & $\begin{array}{c}\text { Lambda } \\
\text { Wilks' } \\
\text { Lambda } \\
\text { Wilks' }\end{array}$ & 0.692 & 130.54 & 881 & .00 & .31 \\
TOP10 Holding & $\begin{array}{c}\text { Wambda } \\
\text { Lambda } \\
\text { Wilks' }\end{array}$ & 0.953 & 1.30 & 881 & .27 & .00 \\
$\begin{array}{c}\text { Fund Star } \\
\text { Rating }\end{array}$ & $\begin{array}{c}\text { Lambda } \\
\text { Wilks' }\end{array}$ & 0.613 & 185.27 & 881 & .00 & .39 \\
$\begin{array}{c}\text { Fund Category } \\
\text { Lambda }\end{array}$ & 0.404 & 107.48 & 2144.27 & .00 & .26 \\
$\begin{array}{c}\text { Fund Star } \\
\text { Rating * Fund } \\
\text { Category }\end{array}$ & $\begin{array}{c}\text { Wilks' } \\
\text { Lambda }\end{array}$ & 0.902 & 10.30 & 2144.27 & .00 & .03 \\
\hline
\end{tabular}

Design: Intercept + STD + TO + TOP10_H + Star Rating + Fund Category + Star Rating * Fund category

Table 4: Tests of Between-Subjects Effects

\begin{tabular}{cccccccc}
\hline Source & $\begin{array}{c}\text { Dependent } \\
\text { Variable }\end{array}$ & $\begin{array}{c}\text { Type III Sum } \\
\text { of Squares }\end{array}$ & df & $\begin{array}{c}\text { Mean } \\
\text { Square }\end{array}$ & F & Sig. $\begin{array}{c}\text { Partial } \\
\text { Eta } \\
\text { Squared }\end{array}$ \\
\hline $\begin{array}{c}\text { Corrected } \\
\text { Model }\end{array}$ & 1-YR & $8737.499 \mathrm{a}$ & 6 & 1456.25 & 107.33 & 0.00 & 0.42 \\
& 3-YR & $7880.511 b$ & 6 & 1313.42 & 308.15 & 0.00 & 0.68 \\
& 5-YR & $2055.164 \mathrm{c}$ & 6 & 342.53 & 225.39 & 0.00 & 0.60 \\
Intercept & 1-YR & 5452.26 & 1 & 5452.26 & 401.84 & 0.00 & 0.31 \\
& 3-YR & 549.91 & 1 & 549.91 & 129.02 & 0.00 & 0.13 \\
& 5-YR & 858.58 & 1 & 858.58 & 564.95 & 0.00 & 0.39 \\
& 1-YR & 6.97 & 1 & 6.97 & 0.51 & 0.47 & 0.00 \\
& 3-YR & 1229.03 & 1 & 1229.03 & 288.36 & 0.00 & 0.25 \\
TO & 5-YR & 164.89 & 1 & 164.89 & 108.50 & 0.00 & 0.11 \\
& 1-YR & 9.54 & 1 & 9.54 & 0.70 & 0.40 & 0.00
\end{tabular}




\begin{tabular}{cccccccc}
\hline Source & $\begin{array}{c}\text { Dependent } \\
\text { Variable }\end{array}$ & $\begin{array}{c}\text { Type III Sum } \\
\text { of Squares }\end{array}$ & df & $\begin{array}{c}\text { Mean } \\
\text { Square }\end{array}$ & F & Sig. & $\begin{array}{c}\text { Partial } \\
\text { Eta } \\
\text { Squared }\end{array}$ \\
\hline \multirow{5}{*}{ 3-YR } & 7.76 & 1 & 7.76 & 1.82 & 0.18 & 0.00 \\
& 5-YR & 21.63 & 1 & 21.63 & 14.23 & 0.00 & 0.02 \\
Fun10-H & 1-YR & 624.27 & 1 & 624.27 & 46.01 & 0.00 & 0.05 \\
& 3-YR & 150.13 & 1 & 150.13 & 35.22 & 0.00 & 0.04 \\
Category & 5-YR & 66.94 & 1 & 66.94 & 44.05 & 0.00 & 0.05 \\
& 1-YR & 3103.86 & 3 & 1034.62 & 76.25 & 0.00 & 0.21 \\
& 3-YR & 2497.87 & 3 & 832.62 & 195.35 & 0.00 & 0.40 \\
& 5-YR & 796.45 & 3 & 265.48 & 174.69 & 0.00 & 0.37 \\
\hline
\end{tabular}

Because the fund categories (three levels) were statistically significant, further tests and subject evaluations were necessary. The post ad hoc tests helped examine the specific performance (1-YR, 3-YR, and 5-YR) association among fund categories (LG, LB, MG, and SG) and covariates (STD, the TO, TOP10-H). The Wilks' Lambda multivariate test results were significant for fund categories (LG, LB, MG, and SG) related to annual returns (1-YR, 3-YR, and 5-YR) holding covariate variables (STD, the TO, TOP10-H). The P $=.00$ for 1-year, 3-year, and 5-year annual returns in support of both hypotheses 1 and 2. The associated effect size (Partial Eta Squared) for 1-year, 3-year, and 5-year were 23\%, 47\%, and $54 \%$, respectively (Appendix 3). The fund star rating (five and four-star) results were statistically significant $(\mathrm{p}<.05)$ related to annualized returns (1-YR, 3-YR, and 5-YR) controlling covariates variables (STD, the TO, TOP10-H) as shown in Appendix 3. The effect size was 3\% for 1-YR, 15\% for $3-Y R$, and $37 \%$ for 37 . The result was consistent with Babalos et al. (2015). The finding indicated that the large growth, blend, and value fund were related to higher fund efficiency based on stochastic frontier analysis (Babalos et al., 2015). An older study concluded that trading inefficiency was experienced in lower size funds (Indro et al., 1999). The blend and value funds experienced significant gains to information and returns than growth funds (Indro et al., 1999). Concerning fund star ratings and fund performance, the result was inconsistent with Galagedera et al. (2018). The investigation found that the Morningstar rating system produced a different and inconsistent result compared to DEA. The covariate turnover rate did not have a statistically significant result $(\mathrm{P}>.05)$ for 1,3 , and 5 -year annual 
returns $(\mathrm{P}>.05)$. Also, the standard deviation (covariate) did not have a statistically significant result for a 1-year annual return $(\mathrm{P}>.05)$ as shown in Appendix 3. This result was inconsistent with Babalos et al.'s (2015) findings. The investigation concluded that higher risk equates to higher fund efficiency (Babalos et al., 2015).

The 1-year annual returns profile plots for large-cap growth and small-cap growth funds showed a similar pattern relative to five and fourstar rating funds. The marginal means for five-star funds declined slightly toward four-star funds. The mid-cap growth significantly declined from five to four-star funds in comparison to all other fund categories. The large-cap blend showed consistent results between five-star and four-star marginal mean differences (Table 5). The marginal means profile plot pattern for large-cap growth, mid-cap growth, and small-cap growth funds for 3-YR annual returns was similar compared to the five and four-star fund ratings. The five-star funds' marginal means declined slightly toward a four-star fund. The mid-cap growth showed a significant decline between five and four-star funds compared to all other fund categories. The marginal means and plots for the large-cap blend pattern were inconsistent between five and four-star compared to all other fund categories (a slightly flattening declining profile). The marginal means and plot pattern for fund categories were consistently declining toward the four-star funds except for 1-YR large-cap blend with a flat profile. There was an interesting observation between the mid-cap and small-cap growth for the 5-YR with a crossover. The crossover indicated an equal result (starting at the same level) and the gap widened and declined toward the four-star points. The Wilks' Lambda was statistically significant that the performances were differently related to five and four-star ratings. Tables 5 and 6 show the marginal means (five and four-star funds and fund categories). It's worth noting that pairwise comparison indicated no statistically significant returns $(\mathrm{P}>.05)$ between mid-cap growth and small-cap growth funds (Appendix 3 ). 
Table 5: Fund Ratings Marginal Means

\begin{tabular}{llcccc}
$\begin{array}{c}\text { Dependent } \\
\text { Variables }\end{array}$ & Rating & Mean & $\begin{array}{c}\text { Std. } \\
\text { Error }\end{array}$ & $\begin{array}{c}\text { 95\% Confidence Interval } \\
\text { Lower } \\
\text { Bound }\end{array}$ & Upper Bound \\
\hline 1-YR & 5 Star & $27.643^{\mathrm{a}}$ & .233 & 27.186 & 28.101 \\
& 4 Star & $26.095^{\mathrm{a}}$ & .168 & 25.766 & 26.424 \\
3 3-YR & 5 Star & $20.547^{\mathrm{a}}$ & .122 & 20.309 & 20.786 \\
& 4 Star & $18.704^{\mathrm{a}}$ & .087 & 18.532 & 18.876 \\
$5-Y R$ & 5 Star & $14.977^{\mathrm{a}}$ & .062 & 14.856 & 15.098 \\
& 4 Star & $13.245^{\mathrm{a}}$ & .044 & 13.158 & 13.332 \\
\hline
\end{tabular}

Table 6: Fund Category Marginal Means

\begin{tabular}{|c|c|c|c|c|c|}
\hline \multirow{2}{*}{$\begin{array}{c}\text { Dependent } \\
\text { Variable }\end{array}$} & \multirow[b]{2}{*}{ Fund Category } & \multirow[b]{2}{*}{ Mean } & \multirow[b]{2}{*}{$\begin{array}{l}\text { Std. } \\
\text { Error }\end{array}$} & \multicolumn{2}{|c|}{$95 \%$ Confidence Interval } \\
\hline & & & & $\begin{array}{l}\text { Lower } \\
\text { Bound }\end{array}$ & $\begin{array}{l}\text { Upper } \\
\text { Bound }\end{array}$ \\
\hline \multirow[t]{4}{*}{ 1-YR } & $\begin{array}{l}\text { Large-cap } \\
\text { Growth }\end{array}$ & $30.369^{a}$ & .247 & 29.884 & 30.854 \\
\hline & $\begin{array}{l}\text { Large-cap } \\
\text { Blend }\end{array}$ & $25.831^{a}$ & .298 & 25.247 & 26.416 \\
\hline & Mid-cap Growth & $27.959^{a}$ & .312 & 27.346 & 28.572 \\
\hline & $\begin{array}{l}\text { Small-cap } \\
\text { Growth }\end{array}$ & $23.318^{a}$ & .435 & 22.465 & 24.171 \\
\hline \multirow[t]{4}{*}{ 3-YR } & $\begin{array}{l}\text { Large-cap } \\
\text { Growth }\end{array}$ & $22.708^{a}$ & .129 & 22.455 & 22.961 \\
\hline & $\begin{array}{l}\text { Large-cap } \\
\text { Blend }\end{array}$ & $17.446^{a}$ & .155 & 17.142 & 17.751 \\
\hline & Mid-cap Growth & $20.000^{a}$ & .163 & 19.681 & 20.320 \\
\hline & $\begin{array}{l}\text { Small-cap } \\
\text { Growth }\end{array}$ & $18.347^{a}$ & .227 & 17.902 & 18.792 \\
\hline \multirow[t]{4}{*}{ 5-YR } & $\begin{array}{l}\text { Large-cap } \\
\text { Growth }\end{array}$ & $15.933^{a}$ & .065 & 15.805 & 16.062 \\
\hline & $\begin{array}{l}\text { Large-cap } \\
\text { Blend }\end{array}$ & $12.756^{\mathrm{a}}$ & .079 & 12.601 & 12.910 \\
\hline & Mid-cap Growth & $14.000^{\mathrm{a}}$ & .083 & 13.838 & 14.163 \\
\hline & $\begin{array}{l}\text { Small-cap } \\
\text { Growth }\end{array}$ & $13.754^{a}$ & .115 & 13.528 & 13.980 \\
\hline
\end{tabular}




\section{Limitation and Implications}

The research constraints included the adequate availability of data that forced the elimination of some data from this study. This investigation could have explored many covariates. This action could have extended and complicated the scope of this study. We assumed the information provided in the Morningstar was accurate. These included the performance calculation metrics (1-YR, 3-YR, and 5-YR) annual returns, and the associated controlling variables (STD, the TO, TOP10-H). Future research should compare the fund categories relative to the benchmark (S\&P 500, etc.), international funds, and incorporate a larger sample size and all levels of the fund star ratings. It would be beneficial to explore other performance metrics such as price book ratio and price-earnings ratios. Lastly, future research can replicate this study to examine the impact of COVID-19. The result would benefit investors to consider fund size as well as the fund style category (large, mid, and small) to make financial decisions. This investigation could provide useful information to investors to identify suitable fund groups to optimize portfolio return (Watson et al., 2011).

\section{DISCUSSION AND CONCLUSIONS}

This investigation revealed that the large-cap growth MF outperformed all other categories (large-cap blend, mid-cap growth, and small-cap growth) in terms of 1-YR, 3-YR, and 5-YR annual returns. The large-cap growth fund category had a lower standard deviation. The five-star than the fourstar rated funds performed better (1-YR, 3-YR, and 5-YR annual returns) considering covariate variables (STD, the TO, and TOP10-H). The turnover rate did not have a statistically significant effect on 1-YR, 3-YR, and 5-YR annual returns. This defeats the purpose of incurring trade-related fees. The same was true for 1-YR relative to standard deviation. Investors should not weigh heavily on the fund's standard deviation relative to a 1-year yield for US equity MF. This holds for the turnover rate relative to 1-YR, 3-YR, and $5-Y R$ annual returns. The non-significant result on standard deviation and turnover was inconsistent with many bodies of research and the principles of finance (Rajkumar \& Rau, 2010). Relative to the principles of finance which suggests that higher risk is equivalent to higher return and higher turnover may result in higher fund performance. 
Investors are better served with five stars Morningstar fund rating than four-star in all fund categories. This opens further research to consider star ratings for all funds. The study by Blake and Morey (2000) suggested that Morningstar was more accurate to predict fund performance relative to 3-star funds than 5-star rated funds. Generally, the Morningstar system provides valuable information compared to alternatives such as Sharpe ratios, Jensen, four-index alphas (Blake \& Morey, 2000). The conclusion was consistent with a prior study that investors should evaluate and consider fund style and size when selecting investment choices and estimating future returns of the US equity MF (Shi \& Seiler, 2002). It is important to note that the large-cap growth produced better performance in 1-YR, 3-YR, and 5-YR annual returns. This was consistent with an earlier study by Chen, et al. (2004) that the large-cap funds produce better performance than small-cap funds regardless of fees and expenses.

\section{REFERENCES}

Ang, A., Madhavan, A., \& Sobczyk, A. (2017). Estimating time-varying factor exposures. Financial Analysts Journal, 73(4), 41-54.

Arshanapalli, B. G., Switzer, L. N., \& Panju, K. (2007). Equity-style timing: A multi-style rotation model for the Russell large-cap and small-cap growth and value style indexes. Journal of Asset Management, 8(1), 9-23.

Arugaslan, O., Edwards, E., \& Samant, A. (2007). Evaluating large USbased equity mutual funds using risk-adjusted performance measures. International Journal of Commerce \& Management, 17(1/2), 6-24.

Babalos, V., Mamatzakis, E. C., \& Matousek, R. (2015). The performance of the US equity mutual fund. Journal of Banking \& Finance, 52, 217-229.

Badrinath, S. G., \& Gubellini, S. (2012). Does conditional mutual fund outperformance exist?. Managerial Finance, 38(12), 1160-1183.

Bekaert, G., \& Wu, G. (2000). Asymmetric volatility and risk in equity markets. The Review of Financial Studies, 13(1), 1-42. 
Bello, Z., \& DeRidder, J. J. (2011). The effects of portfolio concentration on the investment performance of actively managed domestic equity mutual fund, 1990 to 2010. Global Journal of International Business Research, 4(4), 34-47.

Blake, C. R., \& Morey, M. R. (2000). Morningstar Ratings and mutual fund Performance. Journal of Financial \& Quantitative Analysis, 35(3), 451-483.

$\mathrm{Bu}, \mathrm{Q}$. (2019). Risk estimation bias and mutual fund performance. Review of Behavioral Finance, 11(4), 426-440.

Chen, H. L., Jegadeesh, N., \& Wermers, R. (2000). The value of active mutual fund management: An examination of the stockholdings and trades of fund managers. Journal of Financial and quantitative Analysis, 35(3), 343-368.

Chen, J., Hong, H., Ming Huang, \& Kubik, J. D. (2004). Does fund size erode mutual fund performance? The role of liquidity and organization. American Economic Review, 94(5), 1276-1302.

Chopra, M. P. (2011). Do Indian mutual fund managers select the stock and time the market correctly?. IUP Journal of Applied Finance, 17(2), $77-84$.

Cremers, K. M., \& Petajisto, A. (2009). How active is your fund manager? A new measure that predicts performance. The Review of Financial Studies, 22(9), 3329-3365.

Fan, Y. (2018). Position adjusted turnover ratio and mutual fund performance. Studies in Economics and Finance, 35(1), 65-80.

Fischer, M., \& Overkott, M. (2015). Effects of return expectation on mutual fund risk exposures. Journal of Asset Management, 16(3), 156-169.

Fitzpatrick, B. D., Church, J., \& Hasse, C. H. (2012). Specialty funds vs. general mutual fund and socially responsible investment (SRI) funds: An intriguing risk/return paradigm. The Journal of Applied Business and Economics, 13(2), 175-187. 
Galagedera, D. U. A., Roshdi, I., Fukuyama, H., \& Zhu, J. (2018). A new network DEA model for mutual fund performance appraisal: An application to U.S. equity mutual fund. Omega, 77, 168-179.

Goldman, E., Sun, Z., \& Zhou, X. (2016). The effect of management design on the portfolio concentration and performance of a mutual fund. Financial Analysts Journal, 72(4), 49-61.

Gupta-Mukherjee, S. (2013). When active fund managers deviate from their peers: Implications for fund performance. Journal of Banking \& Finance, 37(4), 1286-1305.

Herrmann, U., Rohleder, M., \& Scholz, H. (2016). Does style-shifting activity predict performance? Evidence from equity mutual fund. Quarterly Review of Economics \& Finance, 59, 112-130.

Hsu, J., Myers, B. W., \& Whitby, R. (2016). Timing poorly: A guide to generating poor returns while investing in successful strategies. Journal of Portfolio Management, 42(2), 90-98.

Indro, D. C., Jiang, C. X., Hu, M. V., \& Lee, W. Y. (1999). Mutual fund performance: Does fund size matter? Financial Analysts Journal, 55(3), 74-87.

Investment Company Institute (ICI) (2019). A review of trends and activities in the investment company industry. Retrieved from https:// www.icifactbook.org/deployedfiles/FactBook/Site\%20Properties/ pdf/2019/2019_factbook.pdf.

Kacperczyk, M., Sialm, C., \& Zheng, L. (2008). Unobserved actions of mutual funds. The Review of Financial Studies, 21(6), 2379-2416.

Karoui, A., \& Meier, I. (2015). Fund performance and subsequent risk: A study of mutual fund tournaments using holdings-based measures. Financial Markets and Portfolio Management, 29(1), 1-20.

Kaushik, A., \& Barnhart, S. W. (2009). Do mutual funds with few holdings outperform the market? Journal of Asset Management, 9(6), 398-408. 
Milan, P., \& Eid, W., Junior. (2014). High portfolio turnover and the performance of equity investment funds (high portfolio turnover and performance of equity MF). Revista Brasileira De Finanças, 12(4), 469-497.

Panda, B., \& Moharana, S. (2014). Equity mid-cap mutual fund: Risk and return analysis. Anvesha, 7(3), 45-52.

Park, Y. (2016). The effects of fund commonality in mutual fund families on fund operating expenses and return correlations: Evidence from U.S. equity mutual fund. Financial Services Review, 25(1), 29-49.

Popescu, M., \& Xu, Z. (2017). Market states and mutual fund risk-shifting. Managerial Finance, 43(7), 828-838.

Rahman, S., Lee, C., \& Xiao, Y. (2017). The investment performance, attributes, and investment behavior of ethical equity mutual fund in the US: An empirical investigation. Review of Quantitative Finance and Accounting, 49(1), 91-116.

Rajkumar, M. D., \& Rau, S. S. (2010). Performance evaluation on selecting equity-based Indian mutual fund schemes, using the traditional performance tool. National Journal on Advances in Computing and Management, 1(2), 11.

Shi, S. W. W., \& Seiler, M. J. (2002). Growth and value style comparison of U.S. stock mutual fund. American Business Review, 20(1), 25-32.

Swinkels, L., \& Tjong-A-Tjoe, L. (2007). Can mutual fund time investment styles? Journal of Asset Management, 8(2), 123-132.

Tabachnick, B. G., \& Fidell, L. S. (2012). Using multivariate statistics $\left(6^{\text {th }}\right.$ ed.). London: Pearson.

Vijayakumar N., Murugandan S., \& Chandrashekara, R., (2012). The relationship between fund performance and fund characteristics. IUP Journal of Applied Finance, 18(2), 5-18. 
Walia, N., \& Kumar, R. (2013). Does the portfolio mix influence the mutual fund performance? Asia-Pacific Journal of Management Research and Innovation, 9(4), 413-421.

Watson, J., Wickramanayke, J., \& Premachandra, I. M. (2011). The value of morningstar ratings: Evidence using stochastic data envelopment analysis. Managerial Finance, 37(2), 94-116.

Wermers, R. (2000). Mutual fund performance: An empirical decomposition into stock-picking talent, style, transactions costs, and expenses. The Journal of Finance, 55(4), 1655-1695.

Yalavatti, P., \& Bheemanagouda. (2017). A study on the performance of large-cap equity mutual funds in India. IUP Journal of Financial Risk Management, 14(4), 30-44. 


\section{APPENDICES}

\section{Appendix A: Descriptive of Fund Categories}

\begin{tabular}{|c|c|c|c|c|}
\hline Fund category & Statistic & 1-YR & 3-YR & 5-YR \\
\hline \multirow[t]{7}{*}{ Large-cap Growth } & Mean & 30.61 & 22.34 & 15.61 \\
\hline & Variance & 14.72 & 6.65 & 1.98 \\
\hline & Std. Deviation & 3.84 & 2.58 & 1.41 \\
\hline & Minimum & 20.11 & 16.91 & 12.06 \\
\hline & Maximum & 39.09 & 31.57 & 20.41 \\
\hline & Skewness & $(0.47)$ & 1.48 & 1.09 \\
\hline & Kurtosis & 0.06 & 3.38 & 2.38 \\
\hline \multirow[t]{7}{*}{ Large-cap Blend } & Mean & 25.37 & 15.69 & 12.09 \\
\hline & Variance & 2.95 & 1.28 & 0.37 \\
\hline & Std. Deviation & 1.72 & 1.13 & 0.61 \\
\hline & Minimum & 18.85 & 13.45 & 10.74 \\
\hline & Maximum & 31.92 & 20.13 & 14.40 \\
\hline & Skewness & 1.37 & 1.85 & 1.45 \\
\hline & Kurtosis & 4.89 & 3.74 & 3.05 \\
\hline \multirow[t]{7}{*}{ Mid-cap Growth } & Mean & 27.17 & 20.10 & 13.79 \\
\hline & Variance & 25.13 & 10.02 & 2.10 \\
\hline & Std. Deviation & 5.01 & 3.17 & 1.45 \\
\hline & Minimum & 15.59 & 14.73 & 11.18 \\
\hline & Maximum & 39.09 & 31.28 & 18.54 \\
\hline & Skewness & 0.24 & 1.23 & 1.12 \\
\hline & Kurtosis & $(0.34)$ & 2.21 & 1.61 \\
\hline \multirow[t]{7}{*}{ Small-cap Growth } & Mean & 22.39 & 19.76 & 13.81 \\
\hline & Variance & 19.90 & 7.66 & 3.53 \\
\hline & Std. Deviation & 4.46 & 2.77 & 1.88 \\
\hline & Minimum & 13.85 & 14.20 & 10.77 \\
\hline & Maximum & 35.01 & 28.00 & 20.41 \\
\hline & Skewness & 0.05 & 0.44 & 0.91 \\
\hline & Kurtosis & $(0.64)$ & 0.31 & 1.04 \\
\hline
\end{tabular}




\section{Appendix B: Descriptive of Fund Star Ratings}

\begin{tabular}{llccc}
\hline \multicolumn{1}{c}{ Fund Rating } & \multicolumn{1}{c}{ Statistic } & 1-YR & 3-YR & 5-YR \\
\hline 5 Star & Mean & 28.31 & 21.04 & 15.19 \\
& Variance & 26.62 & 16.34 & 4.77 \\
& Std. Deviation & 5.16 & 4.04 & 2.18 \\
& Minimum & 14.38 & 14.62 & 11.62 \\
& Maximum & 39.09 & 31.57 & 20.41 \\
& Skewness & $(0.04)$ & 0.44 & 0.32 \\
& Kurtosis & $(0.17)$ & $(0.12)$ & $(0.51)$ \\
& Mean & 26.85 & 19.18 & 13.57 \\
& Variance & 21.25 & 10.65 & 2.63 \\
& Std. Deviation & 4.61 & 3.26 & 1.62 \\
& Minimum & 13.85 & 13.45 & 10.74 \\
& Maximum & 39.09 & 31.28 & 20.07 \\
& Skewness & $(0.09)$ & 0.43 & 0.37 \\
& Kurtosis & $(0.24)$ & 0.21 & $(0.55)$ \\
\hline
\end{tabular}

\section{Appendix C: Tests of Between-Subjects Effects}

\begin{tabular}{lcccccc}
\hline \multicolumn{1}{c}{ Source } & DV & SS & MS & F & Sig. & Effect \\
\hline Corrected Model & 1-YR & $9290.600^{\mathrm{a}}$ & 929.060 & 71.448 & .00 & .45 \\
& 3-YR & $8537.413^{\mathrm{b}}$ & 853.741 & 241.335 & .00 & .73 \\
\multirow{3}{*}{ Intercept } & 5-YR & $2598.737^{\mathrm{c}}$ & 259.874 & 285.257 & .00 & .76 \\
& 1-YR & 5551.828 & 5551.828 & 426.954 & .00 & .33 \\
& 3-YR & 720.114 & 720.114 & 203.561 & .00 & .19 \\
Standard Deviation & 5-YR & 1046.026 & 1046.026 & 1148.196 & .00 & .57 \\
& 1-YR & 2.532 & 2.532 & .195 & .66 & .00 \\
& 3-YR & 1026.696 & 1026.696 & 290.226 & .00 & .25 \\
Turnover & 5-YR & 109.223 & 109.223 & 119.891 & .00 & .12 \\
& 1-YR & .259 & .259 & .020 & .89 & .00 \\
& 3-YR & .556 & .556 & .157 & .69 & .00 \\
& 5-YR & 1.083 & 1.083 & 1.189 & .28 & .00
\end{tabular}


Asia-Pacific Management Accounting Journal, Volume 16 Issue 2

\begin{tabular}{lcccccc}
\hline \multicolumn{1}{c}{ Source } & DV & SS & MS & F & Sig. & Effect \\
\hline TOP10 Holding & 1-YR & 455.272 & 455.272 & 35.012 & .00 & .04 \\
& 3-YR & 69.592 & 69.592 & 19.672 & .00 & .02 \\
& 5-YR & 20.412 & 20.412 & 22.406 & .00 & .03 \\
Star Rating & 1-YR & 384.869 & 384.869 & 29.598 & .00 & .03 \\
& 3-YR & 545.143 & 545.143 & 154.101 & .00 & .15 \\
\multirow{5}{*}{ Fund Category } & 5-YR & 481.080 & 481.080 & 528.069 & .00 & .37 \\
& 1-YR & 3423.595 & 1141.198 & 87.762 & .00 & .23 \\
& 3-YR & 2728.896 & 909.632 & 257.134 & .00 & .47 \\
& 5-YR & 940.884 & 313.628 & 344.262 & .00 & .54 \\
\hline
\end{tabular}

\section{Appendix D: Fund Category Pairwise Comparisons}

\begin{tabular}{|c|c|c|c|c|c|c|c|c|c|c|}
\hline \multirow[b]{2}{*}{$\begin{array}{c}\text { Category } \\
\text { (I) }\end{array}$} & \multirow[b]{2}{*}{$\begin{array}{c}\text { Category } \\
\text { (J) }\end{array}$} & \multicolumn{3}{|c|}{ 1-Year } & \multicolumn{3}{|c|}{ 3-Year } & \multicolumn{3}{|c|}{ 5-Year } \\
\hline & & $\begin{array}{c}\text { Mean } \\
\text { Diff. (I-J) }\end{array}$ & $\begin{array}{l}\text { Std. } \\
\text { Error }\end{array}$ & Sig. & $\begin{array}{l}\text { Mean } \\
\text { Diff. } \\
\text { (I-J) }\end{array}$ & $\begin{array}{l}\text { Std. } \\
\text { Error }\end{array}$ & Sig. & $\begin{array}{l}\text { Mean } \\
\text { Diff. } \\
\text { (I-J) }\end{array}$ & $\begin{array}{l}\text { Std. } \\
\text { Error }\end{array}$ & Sig. \\
\hline \multirow[t]{3}{*}{ LG } & LB & 4.54 & .39 & .00 & 5.26 & .20 & .00 & 3.18 & .10 & .00 \\
\hline & MG & 2.41 & .41 & .00 & 2.71 & .21 & .00 & 1.93 & .11 & .00 \\
\hline & SG & 7.05 & .54 & .00 & 4.36 & .28 & .00 & 2.18 & .14 & .00 \\
\hline \multirow[t]{3}{*}{ LB } & LG & -4.54 & .39 & .00 & -5.26 & .20 & .00 & -3.18 & .10 & .00 \\
\hline & MG & -2.13 & .45 & .00 & -2.55 & .23 & .00 & -1.25 & .12 & .00 \\
\hline & SG & 2.51 & .59 & .00 & -.90 & .31 & .02 & -1.00 & .16 & .00 \\
\hline \multirow[t]{3}{*}{ MG } & LG & -2.41 & .41 & .00 & -2.71 & .21 & .00 & -1.93 & .11 & .00 \\
\hline & LB & 2.13 & .45 & .00 & 2.55 & .23 & .00 & 1.25 & .12 & .00 \\
\hline & SG & 4.64 & .50 & .00 & 1.65 & .26 & .00 & .25 & .13 & .38 \\
\hline \multirow[t]{3}{*}{ SG } & LG & -7.05 & .54 & .00 & -4.36 & .28 & .00 & -2.18 & .14 & .00 \\
\hline & LB & -2.51 & .59 & .00 & .90 & .31 & .02 & 1.00 & .16 & .00 \\
\hline & MG & -4.64 & .50 & .00 & -1.65 & .26 & .00 & -.25 & .13 & .38 \\
\hline
\end{tabular}

